\title{
産業廃棄物処理の問題点
}

\author{
一一関係法令の改正にあたって—
}

横田勇*

\section{1. 政令改正の要旨}

愽亲物処理法が施行されて以来, はやくも 1 年半老経 過した. この法律が立法化された主旨およびその目的等 については主管行政庁その他関係各方面から種々の通達 や解説がなされているので, 本稿では省略する・ての法 律を実際に運用する段階に入った現在, 建前と実態との 不一致や乘離についても立法当初と比較して，少しずつ 明らかになってきた，てのたびの政令改正む，有害物質 を含む産業廃育物の処理に関する運用上の困難を解消さ せるべく行なわれたものといえる。それでは今述べた運 用上の困難についてもう少し具体的に説明しよう. 改正 前の政令では有害物質を含む産業廃呆物として次の四種 類

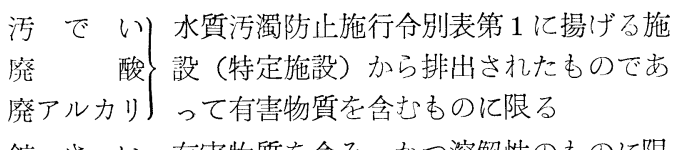

鉱さ い…有害物質を含み，かつ溶解性のものに限 万在定め（「総理府令」）有害物質としては次の6 項目

水銀またはその化合物

カドミウムまたはその化合物

鉛またはその化合物

有機りん化合物

6 価クロム化合物

ひ素またはその化合物

を限定していたが，上の註釈的につけた表現をみても おわかりのように，有害物質を含むあのという表現がな されていたために，いかほどの量を含んでいたとしても 「有害扱かい」する必要があった. それは自然界にでく 普通に見られる程度の含有レベルであっても「有害産 廃」としてのレッテルを貼るてとを意味しており，現実 の廃棄物に対する処理基準の適用を難かしくしていた. そこで今回改正すべき第 1 点として有害物質の含有レ

\footnotetext{
*厚生省環境整備課技官
}

ベルを客観的によらえることのできるような判定基準の 設定（「総理府令」）が行なれれたわけである. 次に，第 2 点としては, 有害物質として新たにシアン化合物が追 加されたことが挙げられよう. いうまであなくシアン化 合物は「毒物劇物取締法」にも規定されているように生 体に対して猛毒であるが, 廃亲物処理法で従来, 有害物 質指定をしなかったのは毒劇法（毒物剢物取締法の略） においてその処理の方法が定めら机ていることのためで あった.しかしながら, 法の目的からして毒劇法は人体 保護在主眼としており, その扱いから対象物もかなり高 純度のものに限定されているので, 種々雑多な物質から なる廃本物中に含まれるシアン化合物の, しかも生活環 境を保全するという立場から見た場合の法制的効果は, はなはだ微力であることが種々の事例を通して次第に明 らかとなった.したがって, 環境保全法としての性格の 强い廃葉物処理法からの手当てが必要亡なったわけであ る.

最後に, 第 3 点としては, 政令第 1 条の 13 号（新旧共 通）の解勫についてである。旧政令では，発棄物はそれ 在処理することによって当初の性状また形態を変えてゆ くこととなるが, 性状または形態の変化につ机て最初の 呼び名をそのつど変えてゆくことはしないという解釈を 採ってきた.すなおち, 污でいを埋立処分するために焼 却処理した後の生成物が污でいというよりはむしろ然え がらの性状に近いものとなったにせよ，污でいは污でい であって然えがらとは呼ばないとしていた．ての解釈は 法制定当時の, 産業廃棄物については全くといってよい ほど体系の未整備な社会的背景においては, 効果的であ ったといえよう. 何故ならば, 多様化した, 夥しい量に のぼる産業廃棄物が, その処理の過程においてそのつど 名称を変えてゆくならば, 法制的な整備すら不可能に近 いと考えられたからである.しかしながらその後運用段 階に入って廃棄物の名称というよりはむしろ廃䢂物を構 成している中味 (=物質) そのあのを重視してゆくやり 方を採用すれば当初予想したような混乱（産業廃棄物の 
種類が限りなく増えてゆくために，処理基隻この他の規 制がかけられなくなるというような）は避けられる見通 しが出てきた.したがって，新政令では法律ならびに政 令（1～12号）で定座業廃呆物を処分するために処 理することによって，元の性状または形態が変化すれば それて応じて名称も変化することとなるが，以上に規定 された産業廃衰物のいず机にも該当しないものが生じた 場合むまた産業廃枽物であること在規定したものであ る.

\section{2. 新政令の記号的解説}

まづ，法定された産業廃䢂物在次のようにひとつひと つ記号 (変数) $\mathrm{x}_{\mathrm{i}}(\mathrm{i}=1,2, \cdots \cdots, 19)$ 亿対応させる。

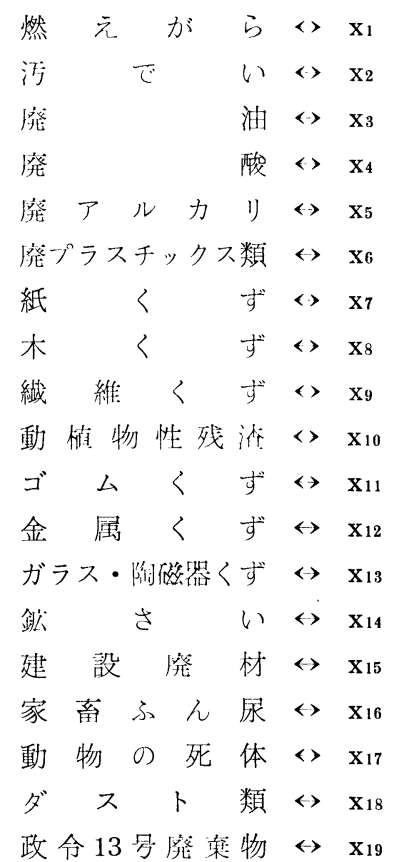

ここに, 最後の政令 13 号笔軬物は, 然えがら $\left(\mathrm{x}_{1}\right)$, 游 でい $\left(\mathrm{x}_{2}\right) ， \cdots \cdots$ 以下, ダス卜類 $\left(\mathrm{x}_{18}\right)$ までの廃呆物在何 らかの方法で処理した結果，元の発裹物（ $x_{1}$ から $\mathrm{x}_{18}$ ま での）上は別な発棄物となったものである，その処理走 一般にP (英語の Processing 処理の頭文字を之った) という文字で表わすことにすると，Pには焼却（P焼） とか脱水（P脱）とかコンクリート固形化 (Pc) 等, い ろいろな種類の処理があるわけで，P焼，P脱， Pc，そ の他考えられるすべての処理方法の集まり（数学でいう “集合”に相当する）をPなる記号で代表させたのであ る.

そこで，例えば“紙くずを焼却処理する”という言葉 を記号化する方法を考えよう. 数学で変量 $\mathrm{X}$ にある演算 $\mathrm{P}$ 在施こすことを $\mathrm{P} ・ \mathrm{X}$ あるいは $\mathrm{P}(\mathrm{X})$ などと書く、乙
の表現方式を採用すれば，紙くず（x7）を焼却処理（P 焼）するとは， $\mathrm{P}$ 焼・ $\mathrm{x}_{7}$ あるいは $\mathrm{P}$ 焼（x7）と書くこと ができる.もし，紙くずを焼却して全部灰（二燃えが ら）になったとす机ば，それを式で書くと，

$$
\mathrm{P} \text { 焼 }\left(\mathrm{x}_{7}\right)=\mathrm{x}_{1}
$$

となるれけである。

政令13号でいう処理は，焼却之か脱水之かを具体的に 規定しているのではなく，こ机らのすべてを含む総称と しての処理であるから $\mathrm{P}$ 在用いて，

$$
\mathrm{P}\left(\mathrm{x}_{\mathbf{i}}\right), \mathrm{i}=1,2, \cdots \cdots \cdots \cdot 18
$$

し表現できう。ただし，この $\mathrm{P}\left(\mathrm{x}_{\mathrm{i}}\right)$ が $\mathrm{i}=1$ から 18 まで の $\mathrm{x}_{\mathrm{i}}$ に該当しないこととなっていろので，政令 13 号廃 杏物を几帳面に式で表現すると

$$
\mathrm{x}_{19}=\left\{\mathrm{P}\left(\mathrm{x}_{\mathrm{i}}\right) \mid \mathrm{P}\left(\mathrm{x}_{\mathrm{i}}\right), \mathrm{x}_{\mathrm{j}}\right\}, \mathrm{i}, \mathrm{j}=1,2, \cdots \cdots, 18
$$

となる。上式の右辺は， $\mathrm{x}_{1}$ から $\mathrm{x}_{18}$ までのいず机にも一 致しないような産業廃染物 $\mathrm{P}\left(\mathrm{x}_{\mathrm{i}}\right)$ の集まりを意味する.

ここで打断わりして扔くが，ある廃裹物が活でい（ $\left.\mathrm{x}_{2}\right)$

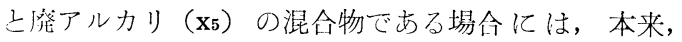
$\mathrm{x}_{2}+\mathrm{x}_{5}$ と貫くバきであるが，式が複雑となるため，簢 略して,

$$
\mathbf{x}_{\mathbf{i}}(\mathbf{i}=2,5)
$$

上䡒くこょ上規約して执く，したがって，上に書か机た $\mathbf{x}_{\mathbf{i}}(\mathbf{i}-1,2, \cdots \cdots, 18)$ には当然是な弓 $\mathbf{i}$ の混命物も含 ま机ていると理解されたい.

次に，問題の政令 6 条の解顥に進むう. 6 条の第一号 は産業発漹物の归立処分の基淮であって，次に示すよう な構成となっている。

$$
\begin{aligned}
& \text { イ, 口 ……産業廃葉物の埋立地に関する総 } \\
& \text { 八, 二, ホ，へ……活でいの坦立処分基淮 } \\
& \text { 卜 ……溌 油の埋立処分基淮 } \\
& \text { チ …発プラスチック類の埋立処分基 }
\end{aligned}
$$

以下，順を追って説明する.

イは，埋立地の周囲にかといを設けるととと，処分場 所の表示を義務づけているものであって，乙れ自体別に 新しい規定ではないが，有害な産業廃棄物（以下，「有 害産廃」という.）として(1)から(4)までを定めている点 が注目すべきであろう。

\section{イ（1）に規定された有害産廃}

水銀に限らず，有害物質走含む，可能性のある污でい （x2）は別表に定めた排出源からの污でいと環境庁長官 
厚生大臣および建設大臣が指定する下水道污でいに特定 されており（以下，乙れをまとめて「特定排出源」とい う.）乙の排出源が特定さ机た活でいを大文字で $\mathrm{X}_{2}$ と 書く.さらにこの $\mathrm{X}_{2}$ が，水銀またはその化合物を含 む場合を $\mathrm{X}_{2}(\mathrm{Hg})$ と書くことにする. そうして，ての $\mathrm{X}_{2}(\mathrm{Hg})$ が総理府令で定めている水銀含有レベル以下で あるか否かを判定することになるが，この結果許容基準 值に

$$
\text { 適合しないもの } \longrightarrow \mathrm{X}^{\prime}{ }_{2}(\mathrm{Hg})
$$$$
\text { 合格するもの } \longrightarrow \mathrm{X}_{2}{ }^{\prime \prime}(\mathrm{Hg})
$$

と対応させる.

$\mathrm{X}_{2}{ }^{\prime \prime}(\mathrm{Hg})$ は, 有害産発とはならず, 通常の污でいの処 理基準だけを満足すればよいが， $\mathrm{X}_{2}{ }^{\prime}(\mathrm{Hg})$ は何らかの特 別な処理が必要である. イ(1)に規定された污でい $\mathrm{X}_{2}{ }^{\prime}$ $(\mathrm{Hg})$ は，その処理としてさらにコンクリート固形化 $\mathrm{Pc}$ を行なっ〔したがって $\mathrm{Pc}\left(\mathrm{X}_{2^{\prime}}(\mathrm{Hg})\right)$ となる.】た後，し や断埋立するかまたは再び総理府命による判定を行な う. 総理府令に

$$
\text { 適合しないもの一 } \longrightarrow \mathrm{Pc}^{\prime}\left(\mathrm{X}_{2}{ }^{\prime}(\mathrm{Hg})\right)
$$$$
\text { 合格したもの } \rightarrow \mathrm{Pc}^{\prime \prime}\left(\mathrm{X}_{\mathbf{2}^{\prime \prime}}(\mathrm{Hg})\right)
$$

と対灾させ，合格した $\mathrm{Pc}^{\prime \prime}\left(\mathrm{X}_{2}{ }^{\prime \prime}(\mathrm{Hg})\right)$ は， $\mathrm{X}_{2}{ }^{\prime \prime}(\mathrm{Hg})$ と 同様に有害産発からはずれることとなり，残りの適合し なかった $\mathrm{Pc}^{\prime}\left(\mathrm{X}_{2}^{\prime}{ }_{2}(\mathrm{Hg})\right)$ が有害産発となり，乙机がすな わちイ(1)に揭げる污でいである，注:

注）イ(1)に規定さ机た污でいとイ(1)に揭げる污でいと は後にホにおいて表現上区別しているので注意が必 要である.すな打ち, 規定さ机た污でいは $\mathrm{X}_{2}(\mathrm{Hg})$ までをいい,“揭げる污でい”は $\mathrm{Pc}^{\prime}\left(\mathrm{X}_{2}{ }^{\prime}(\mathrm{Hg})\right)$ を いう.

\section{イ(2)に規定された有害産廃}

別表の 2 から 6 までの項とは, 順に
2. $\mathrm{Cd}$ とその化合物
3. $\mathrm{Pb}$ とその化合物
4. 有機りんとその化合物
5. 6 価の $\mathrm{Cr}$
6. As とその化合物

であり，乙れを簡略して Cd〜As と書く.イ(1)の場合と 同様に Cd〜As のいずれかを含九特定排出源から生じた 污でいを大文字で，

\section{$\mathrm{X}_{2}(\mathrm{Cd} \sim \mathrm{As})$}

と書く.イ(1)と同様に総理府令に適合しないものにダッ シュ $\mathrm{X}_{2^{\prime}}$ を，合格したものにダブルダッシュ $\mathrm{X}^{\prime \prime}$ をつ ければ，イ(2)に規定された有害産廃は，

$\mathrm{X}_{\mathbf{2}^{\prime}}(\mathrm{Cd} \sim \mathrm{As})$ ¿ $\mathrm{P}^{\prime}\left(\mathrm{X}_{\mathbf{2}^{\prime}}(\mathrm{Cd} \sim \mathrm{As})\right)$

の二種類である.ただし， $\mathrm{P}^{\prime}\left(\mathrm{X}_{2}{ }^{\prime}(\mathrm{Cd} \sim \mathrm{As})\right)$ は，

$\mathrm{X}_{\mathbf{2}^{\prime}}\left(\mathrm{Cd} \sim \mathrm{As}^{\prime}\right)$ に何らかの処理 $\mathrm{P}$ を施こして $\mathrm{P}\left(\mathrm{X}_{\mathbf{2}^{\prime}}{ }^{\prime} \mathrm{Cd}\right.$
〜As)）とし，再び総理府令で判定したところ不合格と なったあのを意味する・ただし， $\mathrm{P}\left(\mathrm{X}_{\mathbf{2}^{\prime}}(\mathrm{Cd} \sim \mathrm{As})\right)$ をし や断埋立する限りにおいて, 総理府令による判定を省略 することができる.

\section{イ(3)に規定された有害産廃}

別表 7 はシアン（CN）化合物を排出する可能性のあ る特定施設である.イ(3)の表現は，イ(1)の表現之同じで あるからイ(1)の $\mathrm{X}_{2^{\prime}}(\mathrm{Hg})$ を $\left.\mathrm{X}_{2^{\prime}}{ }^{\prime} \mathrm{CN}\right)$ に置き換えるだ けでよく,したがって,

$\mathrm{Pc}^{\prime}\left(\mathrm{X}_{2^{\prime}}(\mathrm{CN})\right)$

である・(Pc はコンクリート固形化の意)

\section{イ（4）に規定された有害産廃}

こ狄は, 污でいではなく, 銛さい $\left(\mathrm{x}_{14}\right)$ 亿ついての有 害指定である. シアンを除く六つの有害物質 $(\mathrm{Hg} \sim \mathrm{As})$ を含むむの $\mathrm{x}_{14}(\mathrm{Hg} \sim \mathrm{As})$ のうち，総理府令に適合しな いむの $\mathrm{x}_{14^{\prime}}(\mathrm{Hg} \sim \mathrm{As})$ および，乙机何らかの处理 $\mathrm{P}$ 施こした後, 再び総理府令によって不合格之なったもの

$$
\mathrm{P}^{\prime}\left(\mathrm{x}_{14^{\prime}}(\mathrm{Hg} \sim \mathrm{As})\right)
$$

の二種類がイ(4)に規定さ机た有害鎕さいである.

口の規定す埋立地に関する総括的な規定である.

理立地は, 公共の水域および地下水としゃ断されてい るとととして, まず第1 ステップとしては産廃の埋立地 はすべてしゃ断埋立というアミをかがせる．次に第 2 ス テップとして，「ただし書」により，上に述べたイ(1)か らイ(4)までに揭げた有害産廃以外のものについては，第 1 ステップのしゃ断埋立という強い義務づけを緩和し， 埋立地加らの浸出液に対して，水質污濁防止措置をとる だけでよいとしている.八以下は各論である.

八ニについては，旧政令と同じなので説明を省く．

ホ,では，イ(1)に規定する污でい $\mathrm{X}_{2}(\mathrm{Hg})$ またはこ れを処分するために処理したもの $\mathrm{P}\left(\mathrm{X}_{2}(\mathrm{Hg})\right)$ で総理府 令に不合格となったもの

$\mathrm{X}_{2}{ }^{\prime}(\mathrm{Hg})$ 扩よび $\mathrm{P}^{\prime}\left(\mathrm{X}_{2}(\mathrm{Hg})\right)$ は

(1) 総理府令に適合するような何らかの処理 $\left(\mathrm{P}^{\prime \prime}\right)$ をして，

$$
\mathrm{P}^{\prime \prime}\left(\mathrm{X}_{\mathbf{2}^{\prime}}(\mathrm{Hg})\right)
$$

とするか，

または（いいえかえれば，(1)がダメだった場合は）

(2) コンクリート固形化 Pc を行なって, Hg が漏 れないように

$$
\mathrm{Pc}\left(\mathrm{X}_{\mathbf{2}}{ }^{\prime}(\mathrm{Hg})\right)
$$

としなければならないとしている。しかしながら，イ(1) に揭げた污でい $\mathrm{Pc}^{\prime}\left(\mathrm{X}_{2}{ }^{\prime}(\mathrm{Hg})\right)$ は，一度コンクリート固 形化したものであって，乙れを再びコンクリート固形化 するという非現実的な場合を除外するために，

$\mathrm{P}^{\prime}\left(\mathrm{X}_{\mathbf{2}^{\prime}}(\mathrm{Hg})\right)$ の中から 
$\mathrm{Pc}^{\prime}\left(\mathrm{X}_{2}^{\prime}(\mathrm{Hg})\right)$ を除く という主旨の“カッコ書き”が入れられている.

さて，乙のホの規定はイ(1)の規定とどのようにリンク するのだろうか. (1)によって総理府令にパスしてしまえ ばそれでよいわけであるが，(1)によって基準に適合しな かったときはどうするか?(1)がダメなら(2)へ行けといっ ているのだから，てのときはコンクリート固形化するこ ととなる.ささて，このようにして中の $\mathrm{Hg}$ が漏れない ようにしたコンクリート固形化物を理立地へ持ち運んで 埋立処分しようとするときに，果してしゃ断埋立する必 要があるのかないのかが問題である.そしてての問題を 解决するのがまさしく総理府令であり，乙れてパスすれ ばロのただし書きによる埋立方法でよいし，むし，総理 府令に適合しなければ，それはイ(1)に掍げる污でいとな るから, 有害産廃としての表示やしゃ断埋立が必要とな るととになる・

ヘはホの規定と同様な趣旨のあのであり，ただ有害物 質が $\mathrm{Hg}$ から CN に変わっただけである. $\mathrm{X}_{2}{ }^{\prime}(\mathrm{CN})$ も

(1)総理府令に適合するような処理 $\mathrm{P}^{\prime \prime}$ か，または

(2)コンクリート固形化 Pc

のいずれかが必要とされている。

結論的にいえば，Hg またはシアン在含む場合，総理 府令に合格しない限りはコンクリート固形化が必要であ り，それを行なった後，総理府令で再び不合格となった あのはしゃ盺埋立しなさいといっているのである。

トからヨまでの規定は，旧政令と大差ないので説明を 省略する.

第 6 条の二号も, 廃酸（x4）と廃アルカリ（x5）の垃 立処分を禁止している規定で従前じおりである。

第 6 条第三号は，海洋投入処分できる産業廃棄物を限 定的に列記した規定である.

埋立処分の場合, 有害物質として従前から定められて いた六つの項目（Hg〜As）の他に新しく C Nが追加さ れたように，海洋処分の場合む， C N の規定が新しく付 加されたが，乙のほか海洋においては油分とフェノール もまた有害物質なみの扱いを受ける.

まず項目別に海洋投入処分できるものを列挙すると，
1. 燃えがら

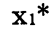
2. 污でい
$\mathrm{x}_{2} *$
3. 金属くず
$\mathrm{X}_{12}$
4. ガラス陶磁器くず $\mathrm{X}_{13}$
5. 鉱さい
$\mathrm{X}_{14}$ *
6. 建設廃材
$\mathrm{X}_{15}$
7. ダスト類
$\mathrm{X}_{18}$
8. 廃酸
$\mathrm{X}_{4} *$
9. 廃アルカリ

10. 動植物性残渣 $\quad \mathrm{x}_{10}$

11. 家畜ふん尿 $\mathrm{X} 16$

となるとの中で $\mathrm{x}$ の右肩に卵をつけた廃育物には有 害物質等を含む場合があるので海洋投入処分の禁止され たものがある、「燃えがら」に有害物質規制が入ったわ けは，有害污でいを焼却すれば「有害燃えがら」となる 可能性があるからである。

そこで有害燃えがらとしては，

$$
\mathrm{X}_{2}{ }^{\prime}(\mathrm{Hg} \sim \mathrm{As})
$$

を焼却処理（P焼）したもの，すなわち

$$
\mathrm{P} \text { 焼 }\left(\mathrm{X}_{2}{ }^{\prime}(\mathrm{Hg} \sim \mathrm{As})\right)
$$

が指定されている.

次に，有害污でいとしては $\mathrm{x}_{2}$ (油分) ……油分を含む汸でい

$\mathrm{x}_{2}\left({ }^{\mathrm{OH}}\right) \ldots . .$. フェ であって排出源の特定され たもの

$\mathrm{X}_{2}{ }^{\prime}(\mathrm{Hg} \sim \mathrm{CN})$

があり，次に，朾害鋕さいとしては $\mathrm{x}^{\prime}{ }_{14}(\mathrm{Hg} \sim \mathrm{As})$

が規定された。

有害咸酸咸アルカリとしては $\mathrm{x}_{\mathrm{i}}$ (油分) ……油分を含む廃酸, 廃アルカリ

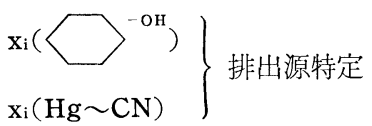

(i=4 また 5)

の三種類が指定されている.

なお，有害活でい $\mathrm{X}_{2}{ }^{\prime}(\mathrm{Hg} \sim \mathrm{CN})$ であっても， Cd か ら As までの有害物質を含まない污でい $\mathrm{X}_{2}{ }^{\prime}(\mathrm{Hg})$ をば い焼( $\mathrm{P}$ ばい焼)して総理府令に適合するようにしたもの

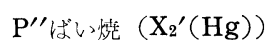

は海洋投入処分可能である。また， $\mathrm{X}_{2}{ }^{\prime}(\mathrm{Hg} \sim \mathrm{Cd})$ をコ ンクリート固形化（Pc）して中に含まれる有害物質が 漏れないようにしたもの

\section{$\operatorname{Pc}\left(\mathrm{X}_{2}{ }^{\prime}(\mathrm{Hg} \sim \mathrm{Cd})\right)$}

あ海洋投入処分可能である.

第 7 条は, 届出等の義務を課される産業廃棄物処理施 設を規定したものである. 旧令との変更点としては，九 号で「有害物質を含む污でいのコンクリート固型化施 設」となっていたのを，「別表の下欄に掍げる物質を含 む污でいのコンクリート固型化施設」と表現が変わり, シアンを含む污でいのコンクート固型化施設が追加され た点が第一点であり，十一号に「污でい，廃酸または廃 アルカリに含まれるシアン化合物の分解施設」が新たに 
追加された点が第 2 点である.

このシアン分解施設の追加によって厚生省令にも一部 改正が行なわれている，それは，省令第十条二号（産業 廃棄物処分業の許可基準) 等において, シアン化合物を 含さ污でい, 廃酸, 発アルカリのシアン尔解施設が付加 されたことである. 現時点で技術的に開発されているシ アン分解施設としては, 次の三種類の施設がある.

(1) 熱分解施設

(2) 電気分解施設

(3) アルカリ塩素法分解施設

このほか，今回の政令政正で，付害物質の投棄海域で ある日本海の $\mathrm{A}$ 海域をずらすととにした。これは昨年11 月, ロンドンの国際会議で海洋投棄規制条約が採択され 有害廃椠物は3500メ一トル以上の深さの海域でしか投棄 できなくなったためで，3000メートルしかない日本海秋 田沖に定めた $\mathrm{A}$ 海城を北に約 $100 \mathrm{Km}$ 移動させることにな ったためである。

最後に, 政令第 6 条の有害産廃に関する処理基隻を, フローシートで表わしたものを罒 1 に揭げ，廃杗物処理 命の改正条文を参考までに掲載した。

\section{廃棄物処理法施行令関係}

(産業廃呆物)

\section{第 1 条}

第 1 条第 13 号を次のように改める.

13 燃えがら, 污でい, 廃油, 廃酸, 廃アルカリ, 廃プ ラスチック類又は前各号に揭げる産業廃棄物を処分す るために処理したむのであって，乙れらの産業廃棄物 に該当しないむの

(産業廃棄物の収集，運搬及び処分の基準)

第 6 条 法第 12 条第 2 項の規定による産業廃裹物の収集 運搬及び処分の基準は，第 3 条第 1 号から第 3 号まで の規定の例によるほか，次のとおりとする.

1 産業廃棄物の埋立処分にあたっては第 3 条第 4 号 ト及びヌの規定によるほか，次によること。

イ 埋立地には，周囲にかこいを設けるとともに， 産業廃棄物の処分の場所（次に揭げる産業廃棄物 の埋立地にあっては，有害な産業廃棄物の処分の 場所）であるととを表示するとと.

（1）別表の 1 の項の中間に掍げる施設を有する工 場若しくは事業場において生じた污でい又は下 水道法施行令（昭昭34年政令第147号）第13条 の 2 の規定により指定された污でい（以下「指 定下水污でい」という.) であって，水銀又は その化合物を含むもの（総理府令で定める基準 に適合しないむのに限る。）を処分するために 処理したもの（コンクリート固型化を行なうこ
とにより当該水銀又はその化合物が漏れないよ うにしたあのであって, 総理府令で定める基準 に適合しないものに限る.)

(2) 別表の 2 の項から 6 の項までの中間に揭げる 施設を有する工場又は事業場において生じた污 でいであってそれぞれとれらの項の下欄に掲げ る物質を含むもの（総理府令で定める基準に適 しないものに限る。）文び指定下水污でいであ って同表の 2 の項から 6 の項までの下欄に揭げ 万物質を含むもの（総理府令で定める基準に適 合しないものに限る・）並びにこ机らの污でい を処分するために処理したもの（総理府令で定 める基準に適合しないものに限る。)

（3）別表の 7 の項の中間に揭げる施設を有する工 場若しくは事業場において生じた污でい又は指 定下水污でいであって，シアン化合物を含むも の）総理府令で定める基準に適合しないものに 限る。）を処分するために処理したもの（コン クリート固型化を行なうことにより当該シアン 化合物が漏机ないようにしたものであって，総 理府令で定める基淮に適合しないものに限る.)

(4) 第 1 条第 8 号に揭げる産業廃棄物であって, 別表の 1 の項より 6 の項までの下欄に掲げる物 質を含むもの（総理府令で定める基準に適合し ないものに限る））及び当該産業廃棄物を処分 するために処理したもの（総理府令で定める基 準に適合しないものに限る。）

口埋立地は，公共の水域及び地下水としゃ楽され ていること・ただし，イ(1)から(4)までに揭げる産 業廃棄物以外の産業廃棄物の理立処分を行なう場 合に拀いて，埋立地からの浸出液によって公共の 水域及び地下水を污染するととのないように必要 な描置を講ずるときは，乙の限りでない.

八 污浩の埋立処分（水面理立処分を除く．）を行 なう場合にはあらかじめ，焼却設備を用いて焼却 し，又は含水率 $85 \%$ 以下にすること.

二 有機性の污でい (※) の水面理立処分を行なう 場合には，あらかじめ焼却設備を用いて焼却する こと

ホイ(1)に規定する污でい又は当該污でいを処分す るために処理したもの（総理府令で定める基準に 適合しない屯のに限るものとし，イ(1)に掍げるも のを除く．）の埋立処分を行なう場合には，あら かじめ，総理府令で定める基準に適合するあのに し，又はコンクリート固型化を行なうことにより これに含まれる水銀若しくはその化合物が漏れな 

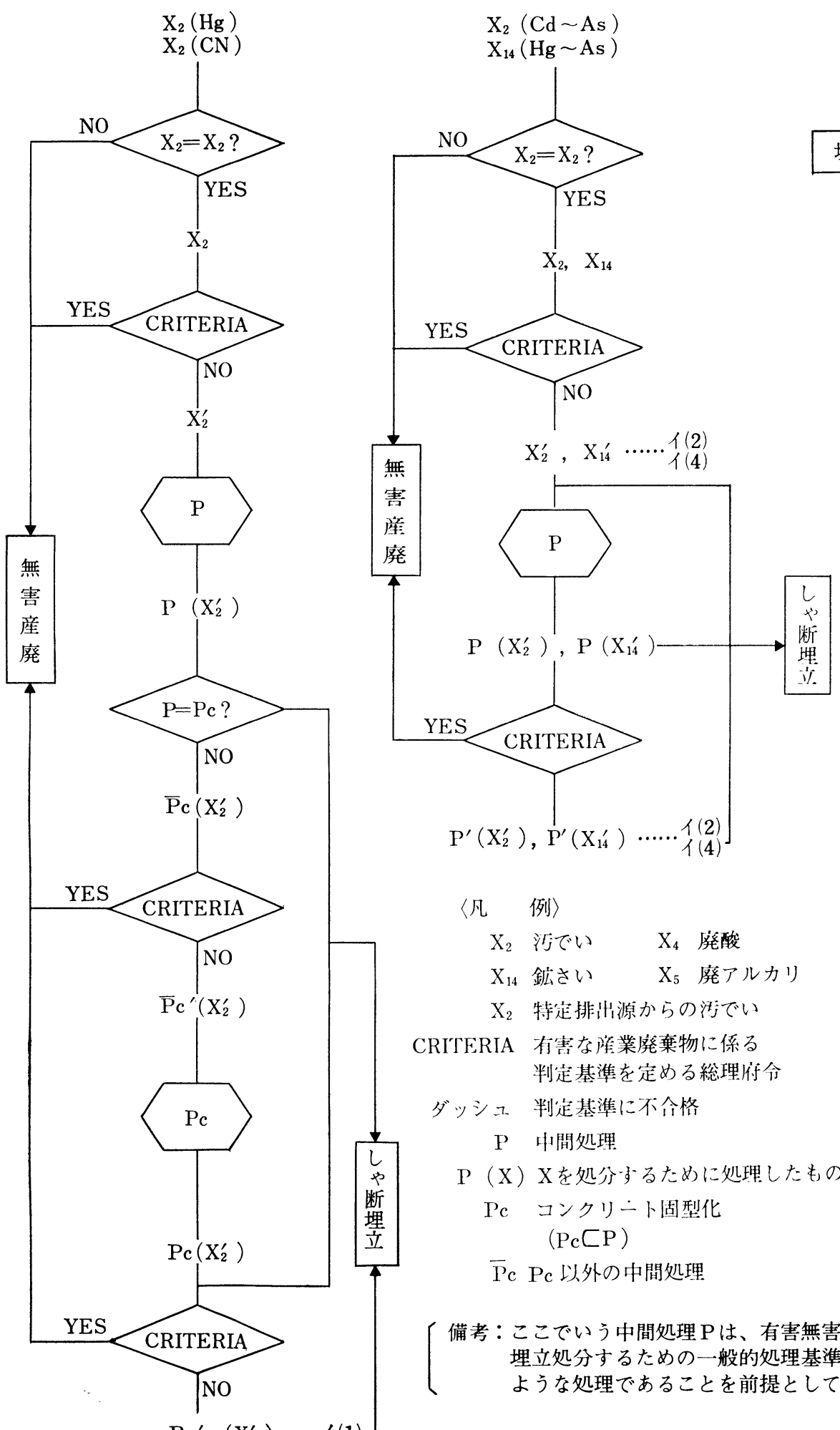

埋立処分禁止

$$
\begin{aligned}
& \text { 〈凡 例〉 } \\
& \mathrm{X}_{2} \text { 污でい } \mathrm{X}_{4} \text { 廃酸 } \\
& \mathrm{X}_{14} \text { 鉱さい } \mathrm{X}_{5} \text { 廃アルカリ }
\end{aligned}
$$

CRITERIA 有害な㦃業廃棄物に係る 判定基準を定める総理付命

ダッシュ 判定基準に不合格

$\mathrm{P}$ 中閒処理

$\mathrm{P}(\mathrm{X}) \mathrm{X}$ を処分守るために処理したもの

$\mathrm{Pc}$ コンクリート固型化

$$
(\mathrm{Pc} \subset \mathrm{P})
$$

$\overline{\mathrm{P}} \mathrm{Pc}$ 以外の中闆処理

〔備考：ここでいう中間処理 Pは、有害無害を問わずに 埋立処分するための一般的処理基準を満足する ような処理であることを前提としている。

$\mathrm{Pc}^{\prime}\left(\mathrm{X}_{2}^{\prime}\right) \cdots \cdots$ イ $(1)$

図 1 政令第 6 条に規定された有害産廃に関するフローシート（埋立処分） 
いようにすること.

へイ(3)に規定する污でい又は当該污でいを処分す るために処理したもの（総理府令で定める基準に 適合しないものに限るものとし，イ(3)に揭げるも のを除く．）の埋立処分を行なう場合には，あら かじめ, 総理府令で定める基準に適合するものに し， 又はコンクリート固型化を行なうことにより これに含まれるシアン化合物が漏れないようにす るとと.

ト 発油 (タールピッチ類を除く.) 埋立処分を行 なう場合には，あらかじめ焼却設備を用いて焼却 するとと.

チ 廃プラスチック類の埋立処分を行なう場合に は, あらかじめ, 中空の状態でないように, かつ, 最大径执むね 15 センチメートル以下に破化し, 切断し, 若しくは溶融設備を用いて溶融加工し, 又は焼却設備を用いて焼却すること.

リ第 1 条第 5 号に揭げる産業廃棄物の埋立処分を 行なう場合にはあらかじめ，最大径お掞むね $15 セ$ ンチメートル以下に破浒し, 若しくは切䉼し, 又 は焼却設備を用いて焼却すること。

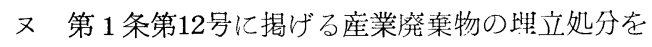
行なう場合には，あらかじめ大気中に飛散しない ようにこん包する等必要な措置を講ずるとと.

ル 腐敗物（有機性の污でい若しくは第 1 条第 4 号 第10号若しくは第11号に掍げる産業廃䢂物又はこ れらの産業発棄物を処分するために処理したもの をいう，ただし，熱しやく減量15\%以下に焼却し たもの「及びコンクリート固型化を行なったも の」を除く，以下同じ））を含む産業廃棄物の埋 立処分を行なう場合には, 埋め立てる産業廃棄物 の一層の厚さは，执打む权 3 メートル（当該産業 発棄物のうち，おおむ标 $40 \%$ 以上が腐敗物である

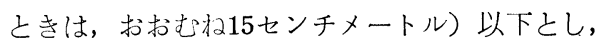
かつ，一層ごとに，その表面を土砂でおおむお括标 センチメートルおおうこと.ただし，小規模埋立 処分を行なう場合又は地中にある空間を利用して 埋立処分を行なう場合は，乙の限りでない。

$\exists$ 腐敗物を含む産業廃棄物の理立処分を行なう場 合には，第13条第 4 号リの規定の例によるとと.

2 廃酸及び廃アルカリは，埋立処分を行なってはな らなこと。

3 産業廃衰物の海洋投入処分は, 次に揭げる産業発 棄物に限り，行なうことができること.

イ 燃えがら（熱しやく減量15\%以下のあのに限る あのとし，(3)又は(4)に揭げる污でいを焼却したも
のを除く.)，污でい（次に掲げるものを除く.）， 第 1 条第 6 号及び第 7 号に揭げる産業廃棄物, 同 条第 8 号に掲げる産業廃育物（別表の 1 の項から 6 の項までの下欄に揭げる物質を含むむのであっ て, 総理府令で定める基準飞適合しないむのを除 く．）並びに同条第 9 号及び第 12 号に掍げる産業 発金物

(1) 油分を含む污でい

（2）水質污濁防止法施行令（昭和46年政令第 188

号）別表第 1 第33号に掲げる施設（フェノール 樹脂の製造業に係るものに限る））を有する工 場又は事業場において生じた污でいであって, フェノール類を含むむの

（3）別表の 1 の項の中間に掲げる施設を有する工 場若しくは事業場において生じた污でい又は指 定下水污でいであって，水銀又はその化合物を 含むむの（総理府令で定める基準に適合しない あのに限る.）

(4) 別表の 2 の項から 6 の項まで中間に揭げる施 設を有する工場又は事業場において生じた污で いであってそれぞれこれらの項の下欄に揭げる 物質を含むもの（総理府令で定める基準に適合 しないものに限る.）及び指定下水污でいであ って同表の 2 の項から 6 の項までの下欄に掍げ る物質を含むむの（総理府令で定める基準に適 合しないものに限る.）仅び指定下水污でいで あって同表の 2 の項から 6 の項までの下欄に掲 げる物質を含むもの（総理府令で定める基淮に 適合しないものに限る.)

(5) 別表の 7 の項の中欄に掍げる施設を有する工 場若しくは事業場において生じた活でい又は指 定下水污でいであって, シアン化合物を含むむ の（総理府令で定める基準に適合しないものに 限る.)

ロイ(3)に揭げる污でい（イ(4)に掲げるあのを除 く.）のばい焼を行なうことにより総理府令で定 める基準に適合するものにしたもの.

八 イ(3)から(5)までに揭げる污でいのコンクリート 固型化を行なうことにより当該活でいに含まれる 別表の下欄に掲げる物質が漏れないようにしたも の

二廃酸又は廃アルカリ（次に揭げるものを除く.） であって, 水素イオン濃度指数 5.0 以上 9.0 以下に したあの

（1）油分を含む廃酸又は廃アルカリ。

（2）イ(2)に規定する工場又は事業場において生じ 
た廃酸又は廃アルカリであって，フェノール類 を含むむの

（3）別表の中間に掍げる施設を有する工場又は事 業場において生じた廃酸又は廃アルカリであっ て，それぞれ同表の下闌に揭げる物質を含むむ の

ホ 第 1 条第 4 号に掲げる産業廃呆物であって, 摩 哗し，かつ，油分を除却したもの

へ 第 1 条第 10 号に揭げる産業発棄物であって, 浮 遊性のきよう雑物を除去したもの

4 前号に規定する産業廃棄物であっても, 埋立処分 を行なうのに特に支障がないと認められる場合には 海洋投入処分を行な打ないようにすること.

※「污でい」の下に「(公共下水道又は流域下水道から 除去した活でいであって，消化設備を用いて消化した あの及び有機物の含有量が消化設備を用いて消化した むの之同程度以下のものを除く. 以下この号において 同じ.)」を加える.

(産業廃㕖物処理施設)

第 7 条 法第15条第 1 項の政介价定める座業発保物処理 施設は，次のと扔りとする。

1 污でいの脱水施没であ，て，1月当たりり処理能

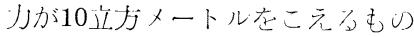

2 污でいの乾燥施設であって，1 日当たりの処理能 力が10立方メートル（天日乾燥施設にあっては 100 立方メートル）をこえるもの

3 污でいの焼却施設であって，1 日当たりの処理能 力が 5 立方メートルをとえるもの

4 廃油の油水分離施設であって，1 日当たりの処理 能力が10立方メートルをてえるむの（海洋污染防止 法（昭和 45 年法律第 136 号）第 3 条第 9 号の廃油処 理施設を除く.)

5 発油の焼却施設であって，1 日当たりの処理能力 が 1 立方メートルをこえるむの（海洋污染防止法第 3 条第 9 号の発油処理施設を除く.)

6 廃酸又は発アルカリの中和施設であって 1 日当た りの処理能力が50立方メートルをてえるもの

7 廃プラスチック類の破浒施設であって，1 日当た りの処理能力が50トンをてえるもの

8 噔プラスチック類の焼却施設であって，1 日当た りの処理能力が 0.1 トンをこえるもの

9 別表の下欄に揭げる物質を含む污消のコンクリー 卜圆型化施設

10 水銀入はその化全物拿屯汸沈のばい焼施設

11 污でい，笔酸又は発アルカリに含ま机るシアン化 伶物0分解施没

別表

1

2
水質污濁防止法施行令別表第 1 （以下「別表第 $1 」$ 上いう.)第25号，第26号イ，口及びホ 第 27 号イ，口，又及びル，第 28 号ホ，第 46 号イ，口及び二，第 47 号口からホまで，第50号 第62号二からへまで並びに第63号二及びホに指げる施設並びにこ机らの施没を有する工場 又は事業場から排出さ机る水の処理施設（下水道終末処理施設を除く．以下同じ.）

別表第 1 第 26 号イから八まで及びホ，第 27 号イ，口，又及びル，第 37 号，第 43 号，第 46 号 イ，口及び二，第50号，第53号，第 62 号小及びへ，第63号八及びホ，第 65 号並びに第 66 号 に掍げる施設並びにこれらの施設を有する工場又は事業場から排出される水の処理施設

別表第 1 第 26 号イ，口及びホ，第 27 号イ，口，又妓びル，第 46 号イ，口及び二，第 47 号口 からホまで，第50号，第53号，第62号ホ及びへ並びに第 63 号八及びホに掍げる施設並びに これらの施設を有する工場父は事業場から排出される水の处理施設

別表第 1 第 46 号イ， ロ及び二，第 49 号並びに第50号に挦げる施設並びにこ机らの施設を有 する工場又は事業場から排出される水の処理施設

別表第 1 第 20 号口，第 26 号イ，口及びホ，第 27 号イ，ロ，又及びル，第 32 号，第 46 号イ， 口及び二，第 47 号口からホまで，第50号，第63号口及びホ，第 65 号亚びに第 66 号に揭げる 施設並びにこれらの施設を有する工場又は事業場から排出される水の処理施設

別表第 122 号口，第 24 号，第 27 号イ，口，又及びル，第 47 号ロからホまで，第 50 号，第 62 号イ，ロ，ホ及びへ並びに第65号に捍げる施設並びにこれらの施設を有する工場又は事業 場から排出される水の処理施設

別表第 1 第 26 号ホ，第 27 号へ及び又，第 28 号イ，第 32 号二，第 33 号口，八及びリ，第 34 号 八からホまで，第 37 号二及びヨ，第 46 号二，第 47 号口からホまで，第 50 号，第 61 号イ，第 63 号イ，第64号，第66号並びに第68号に掍げる施設並びにこれらの施設を有する工場又は 事業場加ら排出される水の処理施設
水銀又はその 化合物

カドミウム又 はその化合物

鈖又はその化 合物

有㙨りん化合 物

六価クロム化 合物

ひ素又はその 化合物

シアン化合物 
埋立処分にかかわる判定基準

総 理 府 令

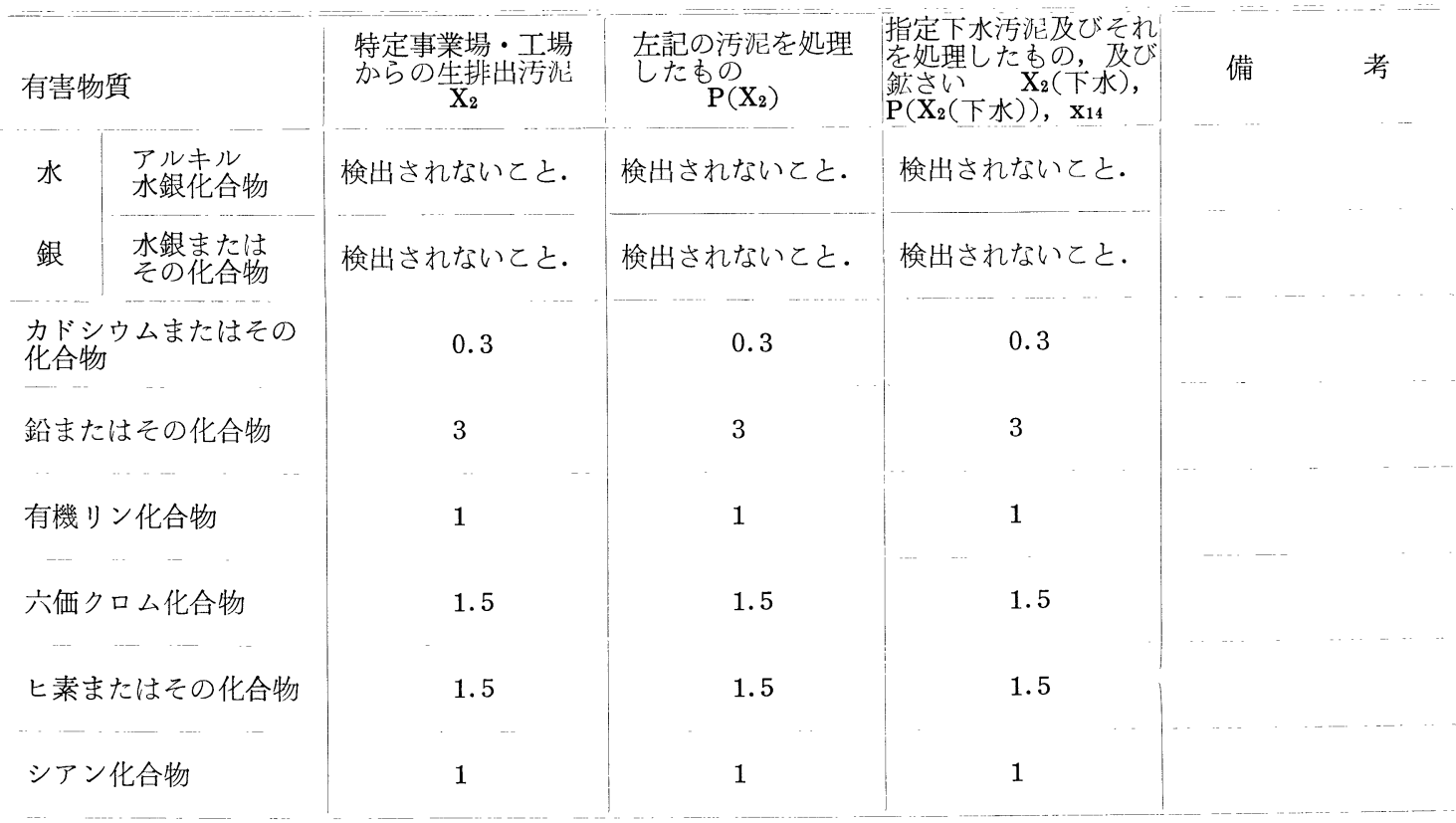

（注） 表中の数字は定められた方法により，物質を溶出させた検液 $1 l$ 中の物質の濃度である. $(\mathrm{mg} / l)$

海洋投入処分にかか加る判定基準

\begin{tabular}{|c|c|c|c|c|c|c|c|}
\hline \multicolumn{2}{|c|}{ 有害物質 } & \multicolumn{2}{|c|}{ 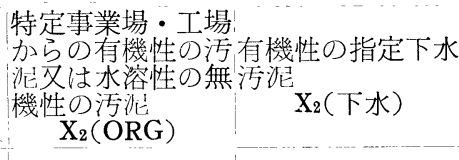 } & \multicolumn{2}{|c|}{ 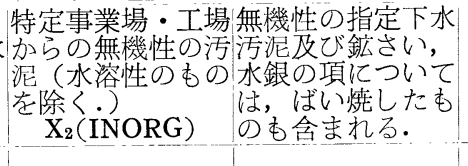 } & 備 & 考 \\
\hline 水 & $\begin{array}{l}\text { アルキル } \\
\text { 水銀化合物 }\end{array}$ & 検出されないこと & 検出されないとと & 上検出されないこと & 検出されないこと & & \\
\hline 銀 & $\begin{array}{l}\text { 水銀または } \\
\text { その化合物 }\end{array}$ & 2 & 2 & 検出されないとと & 検出されないとと & & \\
\hline \multicolumn{2}{|c|}{$\begin{array}{l}\text { カドミウムまたはその } \\
\text { 化合物 }\end{array}$} & 5 & 5 & 0.1 & & & \\
\hline \multirow{2}{*}{\multicolumn{2}{|c|}{$\begin{array}{l}\text { 鉛またはその化合物 } \\
\text { 有機リン化合物 }\end{array}$}} & 50 & 50 & 1 & 1 & & \\
\hline & & 5 & 5 & 1 & 1 & $\ldots$ & \\
\hline \multicolumn{2}{|c|}{ 六価クロム化合物 } & 25 & 25 & 0.5 & 0.5 & & \\
\hline \multicolumn{2}{|c|}{ 七素またはその化合物 } & 25 & 25 & 0.5 & 0.5 & & \\
\hline \multicolumn{2}{|c|}{ シアン化合物 } & 5 & 5 & 1 & 1 & & \\
\hline
\end{tabular}

（注） 表中, 左の二欄の数字は陚料 1 キログラムについての物質の含有濃度である. $(\mathrm{mg} / \mathrm{kg})$ 表中, 右の二欄の数字は検液 1 リットルについての物質の濃度である. $(\mathrm{mg} / l)$ 